\title{
A $\triangle R$ CORRECTION VALUE FOR SAMOA FROM KNOWN-AGE MARINE SHELLS
}

\author{
Matthew B Phelan \\ Radiocarbon Dating Laboratory, School of Science and Technology, University of Waikato, Private Bag 3105, Hamilton, \\ New Zealand
}

ABSTRACT. A first-order $\triangle \mathrm{R}$ correction value for marine samples is presented based on 3 radiocarbon determinations of known-age marine shells from Samoa.

\section{INTRODUCTION}

The modeled marine calibration curves (Stuiver et al. 1986; Stuiver and Braziunas 1993) present a global average of the world ocean response lag to atmospheric variation through time of radiocarbon. Local and regional deviations from this global average complicate the precise calibration of marine samples and, particularly, the chronometric comparison of such samples with terrestrial samples and with marine samples from different regions. A correction value $(\Delta \mathrm{R})$ can be calculated to account for such regional deviations from the modeled marine curve. This may be based on differences between the ${ }^{14} \mathrm{C}$ activity of stratigraphically paired samples of terrestrial and marine origin or on the ${ }^{14} \mathrm{C}$ activity of marine shell samples of known age.

For the central Pacific generally there are very few known $\Delta \mathrm{R}$ values. Stuiver et al. (1986: Table 1) publish 3 values: for Eniwetok, Tahiti, and Hawai'i. This study provides a 4 th $\Delta R$ value for the central Pacific from the Samoan archipelago based on the ${ }^{14} \mathrm{C}$ activity of 3 known-age marine shell samples. These samples were collected by Captain Zembsch, the German Imperial Consul-General in Samoa between 1879 and 1883 (Masterman 1934) and were provided by the Museum für Naturkunde in Berlin. The museum labels attached to the shells note that they were collected between 1881 and 1883 and on this basis calculations are made on a known calendar age of 1882 AD. Although unclear from the information provided, it would seem likely that they were collected from the island of 'Upolu $\left(13^{\circ} 50^{\prime} \mathrm{S}, 172^{\circ} \mathrm{W}\right)$. The mollusc species involved, Turbo petholatus, Strombus pacificus, and Strombus lentiginosus, are all gastropods and coral reef dwellers, preferring shallow intertidal coral sands and rocks (Dance 1992; Cernohorsky 1972).

\section{METHODS}

Samples were washed in an ultrasonic bath and then acid washed $(2 \mathrm{M} \mathrm{HCl})$ for $100 \mathrm{~s}$ to remove the outer shell surface and any possible contaminants. Samples were then hydrolyzed and converted to benzene and ${ }^{14} \mathrm{C}$ activity was determined by liquid scintillation counting (LSC). All samples are reported according to conventions outlined in Stuiver and Polach (1977). The Waikato Laboratory reports ${ }^{14} \mathrm{C}$ results based upon the HOxII reference standard and the ANU sucrose secondary standard. Ages are reported as conventional ${ }^{14} \mathrm{C}$ ages $\mathrm{BP}$ based on the Libby half-life and include a lab error multiplier (K) of 1.22 (Higham and Hogg 1997).

\section{RESULTS}

Samoan known-age marine shell, collected live in 1882, from the collection of the Museum für Naturkunde, Berlin.

Wk 6383

Marine Shell (Turbo petholatus)

$\Delta \mathrm{R}=+70 \pm 40$
$550 \pm 40$

$\delta^{13} \mathrm{C}=+2.0 \%$ 


\section{Wk 6384}

$\Delta \mathrm{R}=+20 \pm 40$

\section{Wk 6385}

$560 \pm 40$

Marine Shell (Strombus lentiginosus)

$\delta^{13} \mathrm{C}=+3.2 \%$

$\Delta \mathrm{R}=+80 \pm 40$

These 3 age determinations are statistically indistinguishable and give an error-weighted mean of $537 \pm 23 \mathrm{BP}$ (Ward and Wilson 1978). Stuiver et al. (1986) provide the formula $\Delta \mathrm{R}=\mathrm{P}-\mathrm{Q}$, where $\mathrm{P}=$ the ${ }^{14} \mathrm{C}$ age of a known-age sample and $\mathrm{Q}=$ the ${ }^{14} \mathrm{C}$ age of the model mixed-ocean layer for the calendar year (AD) of the known-age sample. In other words, $\Delta \mathrm{R}$ is the difference between the modeled ${ }^{14} \mathrm{C}$ age of surface water and the known ${ }^{14} \mathrm{C}$ age of surface water represented by the marine shell sample. In this case $\mathrm{Q}=480 \mathrm{BP}$ (Stuiver and Braziunas 1993) and $\mathrm{P}=537 \pm 23 \mathrm{BP}$. Therefore, $\Delta \mathrm{R}$ $=+57 \pm 23{ }^{14} \mathrm{C}$ yr. This figure remains the same if a $\Delta \mathrm{R}$ value is calculated based on the individual determinations and a weighted mean is calculated on these individual results although the standard error using this method is $\pm 18{ }^{14} \mathrm{C}$ yr. Stuiver and Braziunas (1993) recommend the use of the larger standard error and therefore the standard error of $\pm 23{ }^{14} \mathrm{C}$ yr is used.

\section{DISCUSSION}

A number of studies have recently pointed to the distortion of ${ }^{14} \mathrm{C}$ determinations on marine shell caused by hardwater influx into lagoonal and estuarine environments (Dye 1994; Ingram 1998). In general, the geology of 'Upolu and the Samoan archipelago is of entirely volcanic origin and the only geological carbonates available are Holocene beach sands (Keating 1992; Fox and Cumberland 1962). As all 3 samples are of grazing gastropods it may be possible that some calcium carbonates from the sands are ingested during browsing (Dye 1994). Studies of Strombus gigas from the Bahamas show sand comprising between 58\% and 99\% of gut contents (Stoner and Waite 1991) and, importantly, they note that the "[i]sotope signatures of juvenile conch [Strombus gigas] suggest that the sediments may provide an important source of carbon and nitrogen". Tanaka, Monaghan and Rye (1986) estimate that about 50\% of carbon in mollusc shell derives from metabolic carbon rather than dissolved inorganic carbon (DIC) from the surrounding seawater. The difficulty lies in determining what, if any, fraction of the ingested substrate material might be metabolized. This problem is currently the subject of a doctoral research project. At present, the possibility that Holocene sands may be providing a source of ${ }^{14} \mathrm{C}$-depleted carbon to the samples cannot be excluded with confidence.

Stuiver and Braziunas (1993) note that $\Delta \mathrm{R}$ values represent differences both in regional atmospheric ${ }^{14} \mathrm{C}$ activity and in marine ${ }^{14} \mathrm{C}$ activity due to regional oceanic processes. The data presented here cannot account for variation through time of these variables and as such they provide a first-order $\Delta \mathrm{R}$ value for Samoa. To account for changes in either regional atmospheric ${ }^{14} \mathrm{C}$ activity or changes through time in oceanic processes, a stratigraphic sequence of paired terrestrial/marine samples needs to be analyzed. One paired sample can be found in the archaeological literature. Beta 35603, $2600 \pm 170 \mathrm{BP}\left(\delta^{13} \mathrm{C}=-28.4 \%\right.$, charcoal $)$ and Beta $35604,2770 \pm 80 \mathrm{BP}\left(\delta^{13} \mathrm{C}=+1.7 \%\right.$, Tridacna maxima) are from the To'aga archaeological site in the Manu'a group of American (eastern) Samoa (Kirch 1993) (A Southern Hemisphere correction value has not been applied, as Manu'a is only $14^{\circ}$ south of the equator). These samples yield $\Delta \mathrm{R}=-230$ (Stuiver and Braziunas 1993). This is a number of magnitudes different from the value derived from the known-age samples and indicates either 1) differences between western and eastern Samoa in surface ocean ${ }^{14} \mathrm{C}$ activity, 2) change in regional oceanic processes through time, or 3 ) some problem of association between these 2 determinations. Choosing among these possible explanations is currently a matter of speculation. How- 
ever, the latter option seems the most likely as the Manu'a group is only ca. $100 \mathrm{~km}$ from Western Samoa, a distance over which large-scale oceanic differences in ${ }^{14} \mathrm{C}$ activity are unlikely to vary. In relation to temporal changes in surface ocean ${ }^{14} \mathrm{C}$ activity, independent data relevant to the surface ocean ${ }^{14} \mathrm{C}$ activity at about $2600 \mathrm{BP}$ are not available.

\section{CONCLUSION}

A 1st-order $\Delta \mathrm{R}$ correction value for the Samoan archipelago is calculated at $+57 \pm 23{ }^{14} \mathrm{C}$ yr. This result is part of an ongoing research effort aimed at improving the utility of marine shell as a ${ }^{14} \mathrm{C}$ dating medium for the South Pacific region. Other factors pertinent to the development of reliable and accurate $\Delta \mathrm{R}$ correction values are the effects of 4 independent variables: regional oceanic processes, local environmental conditions, individual species relationship to the carbon cycle, and temporal variation in these factors. The manner in which variation occurs in each of these variables needs to be understood if archaeologists are to develop reliable Pacific chronologies using marine shell as a sample type for ${ }^{14} \mathrm{C}$ dating.

\section{ACKNOWLEDGMENTS}

Thanks go to Dr Matthias Glaubrecht, Museum für Naturkunde, Berlin, for supplying the shells; Dr Tom Higham, University of Waikato Radiocarbon Dating Lab, for comments on the draft manuscript; and Dr Tom Dye, International Archaeological Research Institute, Inc., Hawai'i, for review comments. This research has been supported by a University of Waikato Postgraduate Scholarship.

\section{REFERENCES}

Cernohorsky WO. 1972. Marine shells of the Pacific. Vol 2. Sydney: Pacific Publications. 411 p.

Dance SP. 1992. Shells. London: Harper Collins Publishers. 256 p.

Dye T. 1994. Apparent ages of marine shells: implications for archaeological dating in Hawai'i. Radiocarbon 36(1):51-7.

Fox JW, Cumberland KB. 1962. Western Samoa: land, life and agriculture in tropical Polynesia. Christchurch: Whitcomb and Tombs Ltd. 337 p.

Higham TFG, Hogg AG. 1997. Evidence for late Polynesian colonization of New Zealand: University of Waikato radiocarbon measurements. Radiocarbon 39(2):149-92.

Ingram BL. 1998. Differences in radiocarbon age between shell and charcoal from a Holocene shell mound in Northern California. Quaternary Research 49:102-10.

Keating BH. 1992. Geology of the Samoan Islands. In: Keating BH, Bolton BR, editors. Geology and offshore mineral resources of the Central Pacific Basin. New York: Springer-Verlag. p 127-78.

Kirch PV. 1993. Radiocarbon chronology of the To'aga site. In: Kirch PV, Hunt TL, editors. The To'aga site: three millennia of Polynesian occupation in the
Manu'a Islands, American Samoa. Contributions of the University of California Archaeological Research Facility, nr 51. Berkeley: Archaeological Research Facility. p 85-92.

Masterman S. 1934. The origins of international rivalry in Samoa, 1845-1884. London: George Allen and Unwin, Ltd. 233 p.

Stoner AW, Waite JM. 1991. Trophic biology of Strombus gigas in nursery habitats: diets and food sources in seagrass meadows. Journal of Molluscan Studies 57(4):451-61.

Stuiver M, Braziunas TF. 1993. Modeling atmospheric ${ }^{14} \mathrm{C}$ influences and ${ }^{14} \mathrm{C}$ ages of marine samples to 10,000 BC. Radiocarbon 35(1):137-89.

Stuiver M, Polach HA. 1977. Discussion: reporting of ${ }^{14} \mathrm{C}$ data. Radiocarbon 19(3):355-63.

Stuiver M, Pearson GW, Braziunas T. 1986. Radiocarbon age calibration of marine samples back to $9000 \mathrm{cal} \mathrm{yr}$ BP. Radiocarbon 28(2B):980-1021.

Tanaka N, Monaghan MC, Rye DM. 1986. Contribution of metabolic carbon to mollusc and barnacle shell carbonate. Nature 320:520-3.

Ward GK, Wilson SR. 1978. Procedures for comparing and combining radiocarbon age determinations: a critique. Archaeometry 20(1):19-31 